\title{
Three new helminth species from two endemic plethodontid salamanders, Typhlomolge rathbuni and Eurycea nana, in central Texas
}

\author{
František Moravec ${ }^{1}$ and David G. Huffman ${ }^{2}$ \\ ${ }^{1}$ Institute of Parasitology, Academy of Sciences of the Czech Republic, Branišovská 31, 37005 České Budějovice, Czech \\ Republic; \\ ${ }^{2}$ Freeman Aquatic Station, Southwest Texas State University, San Marcos, Texas 78666-4616, USA
}

Key words: helminth parasites, Amphibiocapillaria, Brachycoelium, Dendronucleata, plethodontid salamanders, Eurycea, Typhlomolge, Texas

\begin{abstract}
Helminthological examination of two rare, endemic species of plethodontid salamanders, the Texas blind salamander (Typhlomolge rathbuni Stejneger) and the San Marcos dwarf salamander (Eurycea nana Bishop), from the subterranean waters and springs in San Marcos, Hays County, central Texas, USA revealed the presence of three new, previously undescribed species of intestinal helminths: Brachycoelium longleyi sp. n. (Trematoda) from T. rathbuni (type host) and E. nana, Dendronucleata americana sp. n. (Acanthocephala) from T. rathbuni, and Amphibiocapillaria texensis sp. n. (Nematoda) from T. rathbuni; nematode larvae probably belonging to the last named species were recorded from E. nana. Brachycoelium longleyi can be distinguished from all congeners primarily by its conspicuously small eggs among other features, whereas $A$. texensis differs from its closest congeneric species A. tritonispunctati mainly in the structure of mature eggs and a markedly shorter spicule. Dendronucleata americana is the first species of the family Dendronucleatidae from the New World, differing from its Asian congeners mainly in the number and arrangement of proboscis hooks, number of giant hypodermic nuclei and in the position of testes.
\end{abstract}

Parasites of insular and relict vertebrates have always been of special interest to parasitologists, but there are often fragmentary or no data on the parasites of many relict species and many of them have not yet been examined helminthologically (Stunkard 1970). Preliminary parasitological investigations of two species of plethodontid salamanders, Typhlomolge rathbuni Stejneger, 1896 and Eurycea nana Bishop, 1941 endemic to the San Marcos area in central Texas, were carried out by D.G. Huffman and his students, but the data were not published (partly included in Longley's [1978] unpublished technical report). Both of these salamander species are protected.

The Texas blind salamander, T. rathbuni, is a highly adapted neotenic cave salamander known only from the Purgatory Creek underground system at San Marcos (San Marcos Pool of the Edwards Aquifer); this extremely rare form has been collected only from two artesian wells, three caves and one spring in the San Marcos area (Young et al. 1973, Longley 1978, 1981, 1986).

The San Marcos dwarf salamander, E. nana, is restricted to the headwater spring area of the San Marcos River, apparently by its very narrow range of tolerance for temperature (Young et al. 1973). The headwaters for this unique river originate from a complex of springs that surface through the Balcones Fault which delineates the Edwards Plateau from the
Blackland Prairie; the temperature for this river varies little from the mean of $22^{\circ} \mathrm{C}$ (yearly range $19-22.5^{\circ} \mathrm{C}$ ) (Michel 1984).

During two short visits of F.M. to Texas in May 1987 and September 1999, several fixed specimens of $T$. rathbuni and $E$. nana were kindly provided for helminthological dissection by Dr. Glenn Longley, the director of Edwards Aquifer Research and Data Center, Southwest Texas State University, in San Marcos. From the intestines of these unique salamanders, three previously unknown helminth species were found, which are described below.

\section{MATERIALS AND METHODS}

Helminth specimens were obtained from salamanders collected by the staff of Edwards Aquifer Research and Data Center, Southwest Texas State University, San Marcos, in the years 1976-1999, and fixed and stored in $70 \%$ ethanol until examination. The salamanders examined included 4 specimens of E. nana, body length 1.5-5.8 cm, collected from Pipe Spring (San Marcos Springs) in 1979-1980, and 29 specimens of $T$. rathbuni, body length $2.4-10.4 \mathrm{~cm}$, collected from the artesian well on the campus of the Southwest Texas State University (Freeman Aquatic Station), San Marcos (21 specimens) and Pipe Spring (San Marcos Springs) (8 specimens) in 1976-1999.

Prior to necropsy, the salamanders were transferred to distilled water for $24 \mathrm{~h}$. Helminth specimens had been fixed

Address for correspondence: F. Moravec, Institute of Parasitology, Academy of Sciences of the Czech Republic, Branišovská 31 , 370 05 České Budějovice, Czech Republic. Phone: ++420 38777 5432; Fax: ++420 38 5300388; E-mail: moravec@paru.cas.cz 
in situ by $70 \%$ ethanol preservation of their amphibian hosts. All helminths recovered were stored temporarily in $4 \%$ formalin. The trematodes and acanthocephalans were removed from formalin and placed in distilled water for $24 \mathrm{~h}$ and then pressed between two glasses and post-fixed in $10 \%$ formalin for $24 \mathrm{~h}$ to keep the body shape; subsequently they were stained with Schuberg's carmine, dehydrated and mounted as permanent preparations in Canada balsam. Nematodes were removed from formalin and cleared in glycerine; after examination, they were mounted in glycerine-jelly. Drawings were made with the aid of a Zeiss microscope drawing attachment. All measurements are given in millimetres. Type specimens are deposited in the US National Parasite Collection, Beltsville, Maryland, USA and in the Helminthological Collection of the Institute of Parasitology, Academy of Sciences of the Czech Republic (ASCR) in České Budějovice, Czech Republic.

\section{REVIEW OF SPECIES}

\section{TREMATODA}

Family: B r a c h y c o e 1 i i d a e Looss, 1899

\section{Brachycoelium longleyi sp. $\mathrm{n}$.}

Figs. 1, 2A

Description (1 specimen [holotype] from T. rathbuni and four specimens [paratypes] from E. nana; measurements of holotype in parentheses): Body oval, 0.7211.010 (0.721) long, maximum width 0.476-0.571 (0.476). Fine dermal spines present on whole body, their length on anterior part of body 0.009 (0.009). Oral sucker subterminal, somewhat larger than acetabulum; size of oral sucker $0.120-0.195 \times 0.084-0.138(0.120 \times$ $0.084)$, of acetabulum 0.096-0.135 × 0.090-0.126 (0.096 $\times 0.090$ ). Prepharynx indistinct. Muscular pharynx oval, measuring $0.027-0.030 \times 0.030-0.033(0.030 \times 0.030)$; oesophagus markedly short, $0.045(0.045)$ long. Caeca short, wide, divergent, extending to posterior border of acetabulum. Testes spherical to oval, lateral, on same level, equatorial or just post-equatorial, mostly posterior to acetabulum. Genital pore just preacetabular. Cirrus pouch 0.114-0.216 (0.114) long and 0.042-0.057 (0.057) wide, dorsal to acetabulum, usually extending posteriorly to its posterior border. Ovary subspherical to transversely oval, size $0.096-0.135 \times 0.081-0.093(0.096$ $\times 0.090$ ), pretesticular, either on left or right of body at level of posterior part of acetabulum or just posterior to it. Ootype, Laurer's canal and seminal receptacle indistinct. Eggs yellow-brown, oval, operculate, size $0.021-0.027 \times 0.012-0.015(0.021-0.024 \times 0.012)$. Uterine loops filling posterior half of body and space between testes and acetabulum. Vitellaria forming two lateral clusters of follicles between pharynx and ovary; number of follicles in each cluster 8-17 (10 and 15). Excretory vesicle not observed.

$\mathrm{T}$ y $\mathrm{p}$ e $\mathrm{h}$ o s $\mathrm{t}$ : Texas blind salamander, Typhlomolge rathbuni Stejneger (Plethodontidae, Amphibia).

O t h e r h o s t: San Marcos dwarf salamander, Eurycea nana Bishop (Plethodontidae, Amphibia).
Site of infection: Intestine.

T y p e 1 o c a 1 i t y : Spring Pipe (San Marcos Springs), San Marcos, Hays County, central Texas, USA (holotype collected 15 February 1999).

P reva 1 e n c e a n d i n e n s it y: T. rathbuni: $13 \%$ (1 salamander infected / 8 examined), 1 trematode; E. nana: $25 \%(1 / 4), 4$.

D e p o s it i o n of ty pes: Holotype and 1 paratype in US National Parasite Collection, Beltsville, Maryland (Cat. Nos. 089433.00 and 089434.00), 3 paratypes in Institute of Parasitology, ASCR, in České Budějovice (Cat. No. D435).

E t y m o lo g y: This new trematode species has been named in honour of Dr. Glenn Longley, the director of Edwards Aquifer Research and Data Center, Southwest Texas State University, San Marcos, who provided the unique host salamanders for helminthological examination. Dr. Longley has been very active in surveying and describing the unusually rich biota of the Edwards Aquifer and is widely recognised for his authoritative contributions in this discipline.

Comments: Although a number of species of the genus Brachycoelium Dujardin, 1845 had been described from North American amphibians, Rankin (1938) synonymised all of them (14 species) with the holarctic species B. salamandrae (Froelich, 1789), originally described from European caudate amphibians. However, this has not been recognised by subsequent authors such as Parker (1941), Cheng (1958), Cheng and Chase (1961) and Couch (1966) who, after careful studies of their specimens, showed that there were enough distinct characters to recognise 13 species of this genus in North America: B. amblystomae Couch, 1966, B. daviesi Harwood, 1932, B. elongatum Cheng, 1958, B. georgianum Byrd, 1937, B. louisianae Byrd, 1937, B. meridionale Harwood, 1932, B. mesorchium Byrd, 1937, B. obesum Nicoll, 1914, B. ovale Byrd, 1937 (? syn. of B. obesum), B. salamandrae (Froelich, 1789), B. stablefordi Cheng et Chase, 1961, B. storeiae Harwood, 1932, and B. trituri Holl, 1928.

Of these 13 species, considering such features as the shape and the size of body, character of vitellaria and location of suckers and genital organs, the new species is closest to $B$. ovale Byrd, 1937, considered a synonym of B. obesum Nicoll, 1914 by Cheng (1958) (see keys given by Byrd [1937] and Cheng [1958]). Both B. ovale and $B$. obesum have been reported from North American plethodontid salamanders of the genera Desmognathus, Eurycea and Plethodon (see Parker 1941, Cheng 1958), in addition to the reptilian host (a skink from Louisiana) from which $B$. ovale was originally described. However, in contrast to the above mentioned species, $B$. longleyi has conspicuously much smaller eggs, being approximately half the size of those in B. ovale and B. obesum $(0.021-0.027 \times 0.012-0.015$ $\mathrm{mm}$ vs. $0.039-0.045 \times 0.027-0.030 \mathrm{~mm}$ or $0.050-0.052$ $\times 0.034-0.036 \mathrm{~mm}$, respectively); moreover, its caeca 
A

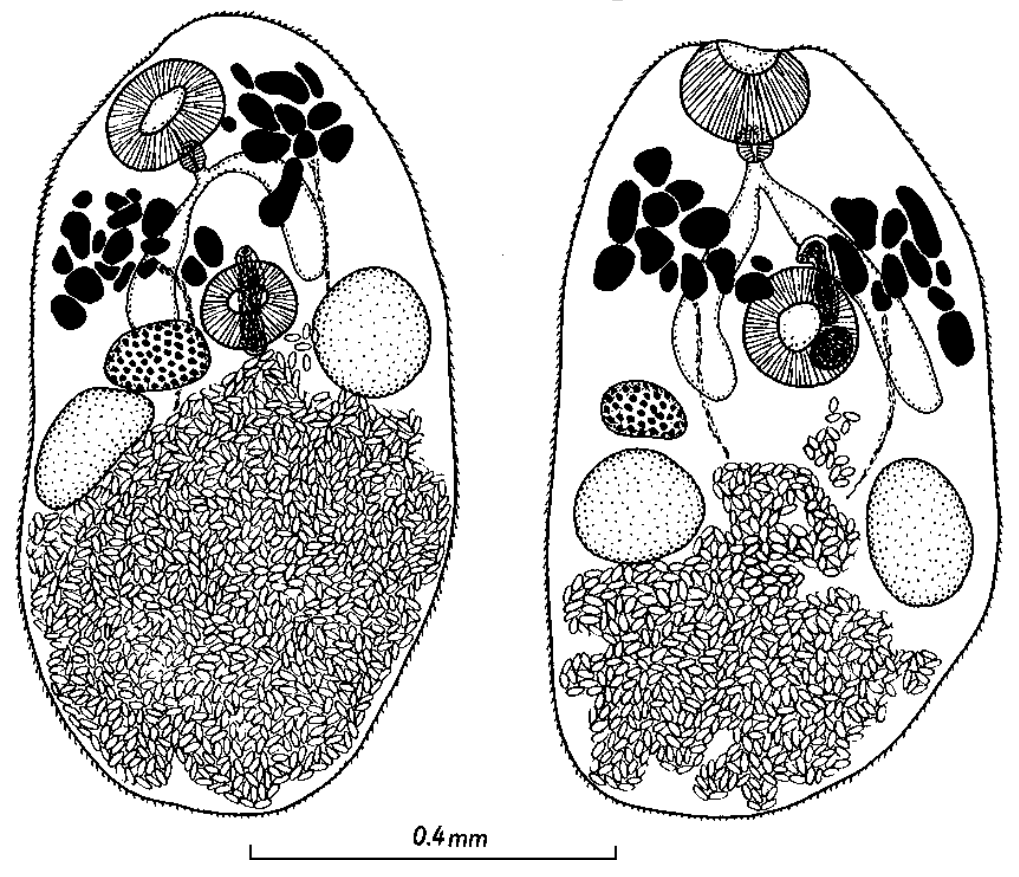

C

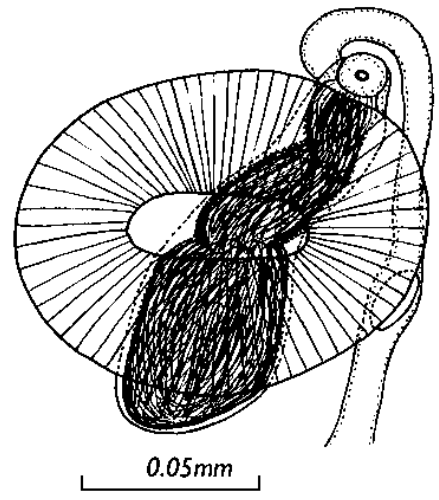

D

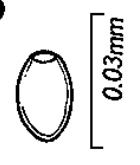

Fig. 1. Brachycoelium longleyi sp. n., paratypes from Eurycea nana. A, B - two different specimens, ventral views; C acetabulum region with cirrus pouch; D - egg.

extend posteriorly to the level of acetabulum, sometimes exceeding its posterior border (see variations in Figs. $1 \mathrm{~A}, \mathrm{~B}$ and $2 \mathrm{~A}$ ).

The markedly small size of eggs in B. longleyi is a unique feature of this species by which it differs not only from all other North American members of the genus but from all hitherto described congeneric species, in which the length of eggs ranges within 0.039-0.066 mm (Yamaguti 1971, Moravec 1984). Brachycoelium longleyi can also be distinguished from the other species by other morphological features.

\section{ACANTHOCEPHALA}

Family: D e n d r o n u c l e a t i d a e Sokolovskaya in Bykhovskaya-Pavlovskaya et al., 1962

\section{Dendronucleata americana sp. $\mathrm{n}$.}

Fig. 2 B-J

Description: Body elongate, somewhat broader anteriorly, with 6-7 dendritically branched giant hypodermic nuclei irregularly distributed in body wall. Two anteriormost giant nuclei situated subdorsally and subventrally at the same level, forming a pair; few nuclei clearly coupled closely to one another (Fig. 2 D, E). Small proboscis spheroid, armed with hooks arranged in six spiral rows of three hooks each. Size of hooks decreasing posteriad; roots of anterior hooks with small anterior process. Neck very short. Proboscis receptacle short, with cephalic ganglion at its base. Lemnisci relatively short, one bearing two simple, rounded giant nuclei, another one with only one giant nucleus; all nuclei located in anterior halves of lemnisci.

Male (3 specimens; measurements of holotype in parentheses): Length of trunk 1.945-2.965 (2.584), maximum width 0.367-0.462 (0.367). Proboscis 0.109$0.122(0.122)$ long and $0.136(0.136)$ wide. Neck indistinct. Length of anterior hooks 0.039-0.042 (0.0390.042 ), of middle hooks 0.012 (0.012), and of posterior hooks 0.009-0.012 (0.009-0.012). Proboscis receptacle 0.150-0.272 (0.163) long and 0.095-0.109 (0.109) wide. Lemnisci $0.408-0.530(0.435)$ and $0.449-0.666(0.666)$ long and 0.054-0.095 (0.081) and 0.068-0.109 (0.081) wide. Testes almost spherical, tandem, situated at posterior quarter of trunk; anterior testis 0.204-0.218 $\times$ $0.177-0.218(0.204 \times 0.177)$, posterior testis $0.204-$ $0.218 \times 0.190-0.231(0.204 \times 0.190)$. Cement gland syncytial, with several distinct nuclei, forming almost spherical mass below posterior testis; cement gland $0.136-0.163$ (0.136) long and 0.150-0.163 (0.163) wide. Bell-shaped bursa 0.163-0.245 (0.204) long and 0.1630.177 (0.177) wide.

Female (3 specimens; measurements of allotype in parentheses): Length of trunk 3.155-3.944 (3.944 incomplete specimen), maximum width $0.435-0.517$ (0.517). Proboscis 0.109-0.136 (0.136) long and 0.136 

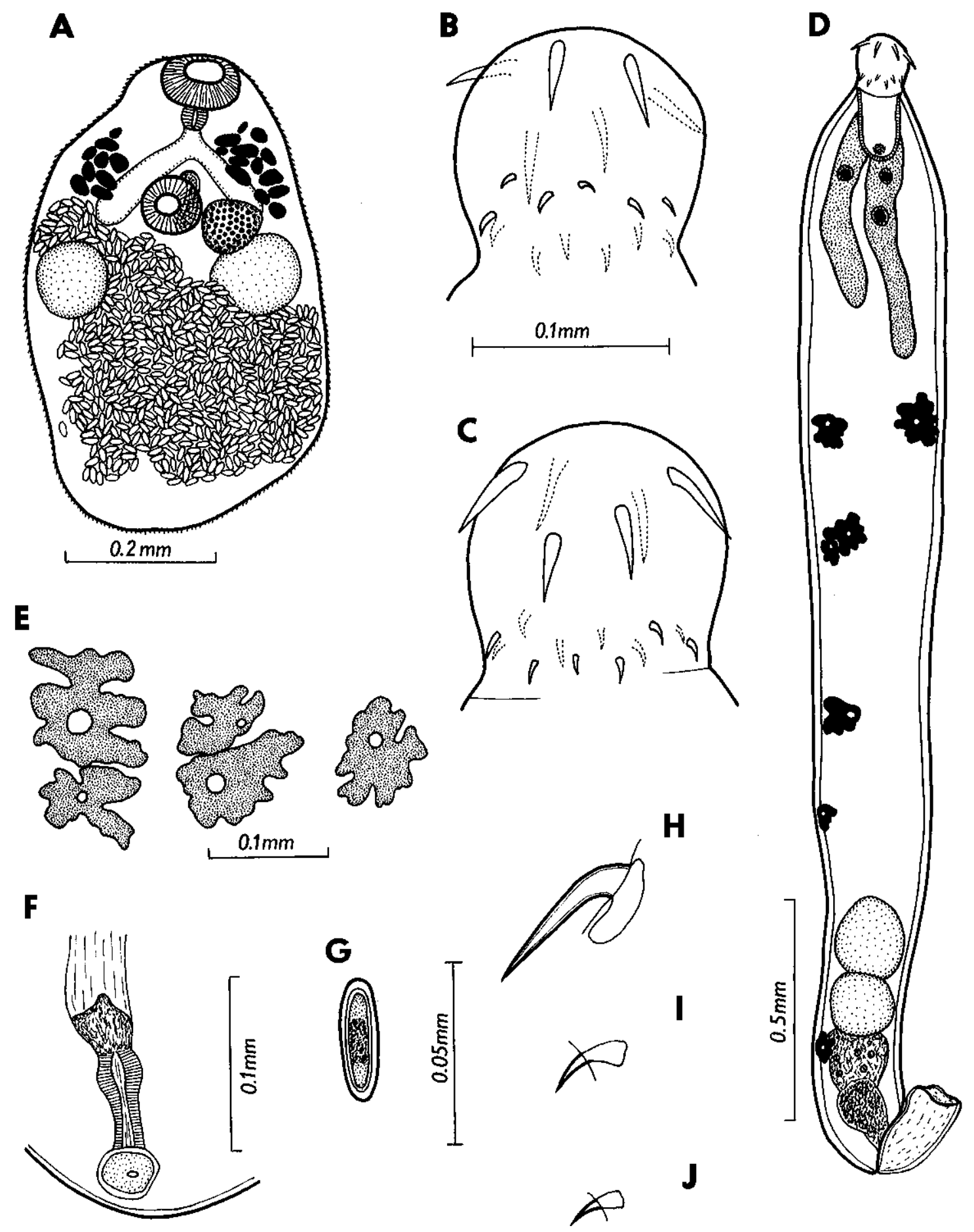

Fig. 2. A-Brachycoelium longleyi sp. n., holotype from Typhlomolge rathbuni, ventral view. B-J - Dendronucleata americana sp. n. (B, C - male and female proboscis, respectively; $\mathbf{D}$ - male, total view; $\mathbf{E}$ - dendritically branched giant hypodermic nuclei; $\mathbf{F}$ - region of vaginal sphincter; $\mathbf{G}$ - egg; H-J - anterior, middle and posterior proboscis hooks, respectively). 
(0.136) wide. Neck (0.041) long and (0.150) wide in allotype, but indistinct in paratypes. In allotype, length of anterior hooks (0.045), of middle hooks (0.012), and of posterior hooks (0.009); proboscis in both paratypes invaginated and, therefore, hooks not measured. Proboscis receptacle $0.177-0.286(0.177)$ long and 0.122-0.136 (0.122) wide. Lemnisci 0.612-0.884 (0.884) and 0.816-0.966 (0.816) long and 0.068-0.095 (0.095) and 0.068-0.109 (0.109) wide. Body cavity filled with small ovarian balls 0.045-0.054 (-) in diameter. Spherical vaginal sphincter distinct, gonopore terminal. Eggs oval, size $0.033-0.036 \times 0.012(0.036 \times 0.012)$.

$\mathrm{T}$ y $\mathrm{p}$ e $\mathrm{h}$ o s t : Texas blind salamander, Typhlomolge rathbuni Stejneger (body length $7 \mathrm{~cm}$ ) (Plethodontidae, Amphibia).

T y p e 1 o c a 1 i t y : San Marcos (Artesian well at Freeman Aquatic Station), Hays County, central Texas, USA.

$\mathrm{Prevalence}$ a nd inten sit y: $5 \%$ (1 salamander infected / 21 examined), 7 acanthocephalans.

D e p o s i t i o n of ty p e s : Holotype and allotype in US National Parasite Collection, Beltsville, Maryland (Cat. Nos. 089431.00 and 089432.00), paratypes in Institute of Parasitology, ASCR, in České Budějovice (Cat. No. A-67).

E t y m o lo g y: The specific name of this species relates to the continent where it was found, i. e. America.

Comments: Although the general appearance, shape of proboscis and number and arrangement of proboscis hooks of these acanthocephalans are similar to members of Neoechinorhynchus Stiles et Hassall, 1905 of the family Neoechinorhynchidae, the presence of randomly distributed dendritically branched giant hypodermic nuclei shows unequivocally that they belong to the family Dendronucleatidae (see Amin 1987). The latter monotypic family was created by Sokolovskaya in Bykhovskaya-Pavlovskaya et al. (1962) to accommodate the only genus Dendronucleata Sokolovskaya in Bykhovskaya-Pavlovskaya et al., 1962, containing two species, Dendronucleata dogieli Sokolovskaya in Bykhovskaya-Pavlovskaya et al., 1962 and D. petruschewskii Sokolovskaya in Bykhovskaya-Pavlovskaya et al., 1962, both described from Far Eastern freshwater cyprinid fishes (the Amur River basin) (Sokolovskaya 1962, 1971). Later Moravec and Sey (1989) recorded $D$. petruschewskii from eight species of cyprinid and bagrid fishes from North Vietnam and remarked that $D$. dogieli and D. petruschewskii might be conspecific.

In contrast to the diagnosis of Dendronucleata, the specimens of the new species have less numerous ( 3 instead of 4) hooks in each spiral row and only 6-7 (instead of about 20) dendritically branched giant hypodermic nuclei. But we consider these differences insufficient for creation of a new genus and, therefore, we assign these acanthocephalans to Dendronucleata the diagnosis of which should be, however, changed as follows: "Body spindle-shaped or cylindrical, ventrally curved. Dendritically branched giant hypodermic nuclei irregularly scattered in body wall of entire trunk, 6-20 in number. Each lemniscus containing 1-3 rounded giant nuclei. Proboscis spheroid, armed with 18-24 hooks arranged in 6 spiral rows. Cephalic ganglion in posterior part of proboscis receptacle. Intestinal parasites of fishes and amphibians."

In addition to the above mentioned differences between $D$. americana and $D$. dogieli and D. petruschewskii, the new species differs considerably from the two last named species in the position of testes (near the posterior end vs. in mid-body), the number of giant nuclei in lemnisci (1-2 vs. 2-3), shape of the trunk, length of proboscis hooks, length of eggs (0.033-0.036 $\mathrm{mm}$ vs. $0.041-0.044 \mathrm{~mm}$ ), and in some other features.

\section{NEMATODA}

Family: C a p i 11 a ri i d a e Railliet, 1915

Amphibiocapillaria texensis sp. n.

Fig. 3

Description: Small, fine nematodes; cephalic end narrowed, rounded, provided with inconspicuous oral papillae. Two hardly visible lateral bacillary bands extending along almost whole body. Stichosome formed by single row of about 100 short stichocytes with large nuclei; nuclei not arranged in one continuous row, especially in posterior part of stichosome, being often shifted to right or left sides of stichocytes; many stichocytes subdivided into two transverse annuli.

Male (holotype: caudal end of 1 specimen): Length of body fragment 0.906 , maximum width 0.033 . Spicule, except for its distal end, strongly sclerotised, with numerous rough transverse grooves on its surface; proximal end of spicule moderately expanded, distal end rounded. Length of spicule 0.162 , width at its proximal end, middle portion and distal end 0.009, 0.008 and 0.006 , respectively. Spicular sheath covered by numerous small spines. Caudal end rounded, provided with a wide cuticular membrane forming a bursa 0.009 long and 0.021 wide. Bursa supported by two fingershaped lateral rays curved to median line. Pair of large, round subventral papillae situated on either side of cloacal opening. Latter 0.015 from posterior extremity.

Female ( 9 complete or incomplete specimens; measurements of allotype in parentheses): Body of females containing mature or immature eggs 3.781-5.277 (incomplete body 4.420), maximum width $0.054-0.068$ (0.068). Width of lateral bacillary bands at mid-body $0.012-0.030$ (0.024). Length of entire oesophagus 2.176-2.910 (2.761), forming 47-58 (-) \% of body length. Length of muscular oesophagus $0.159-0.294$ $(0.264)$, distance of nerve ring from anterior end 0.045 0.078 (-); stichosome 1.903-2.751 (2.497) long. Vulva situated $0-0.030(0.012)$ posterior to level of oesophagus. Vulvar lips not elevated. Eggs in uterus arranged in one row near vulva; up to 15 mature eggs present in uterus. Fully developed eggs barrel-shaped, with distinctly protruding polar plugs. Egg wall two- 

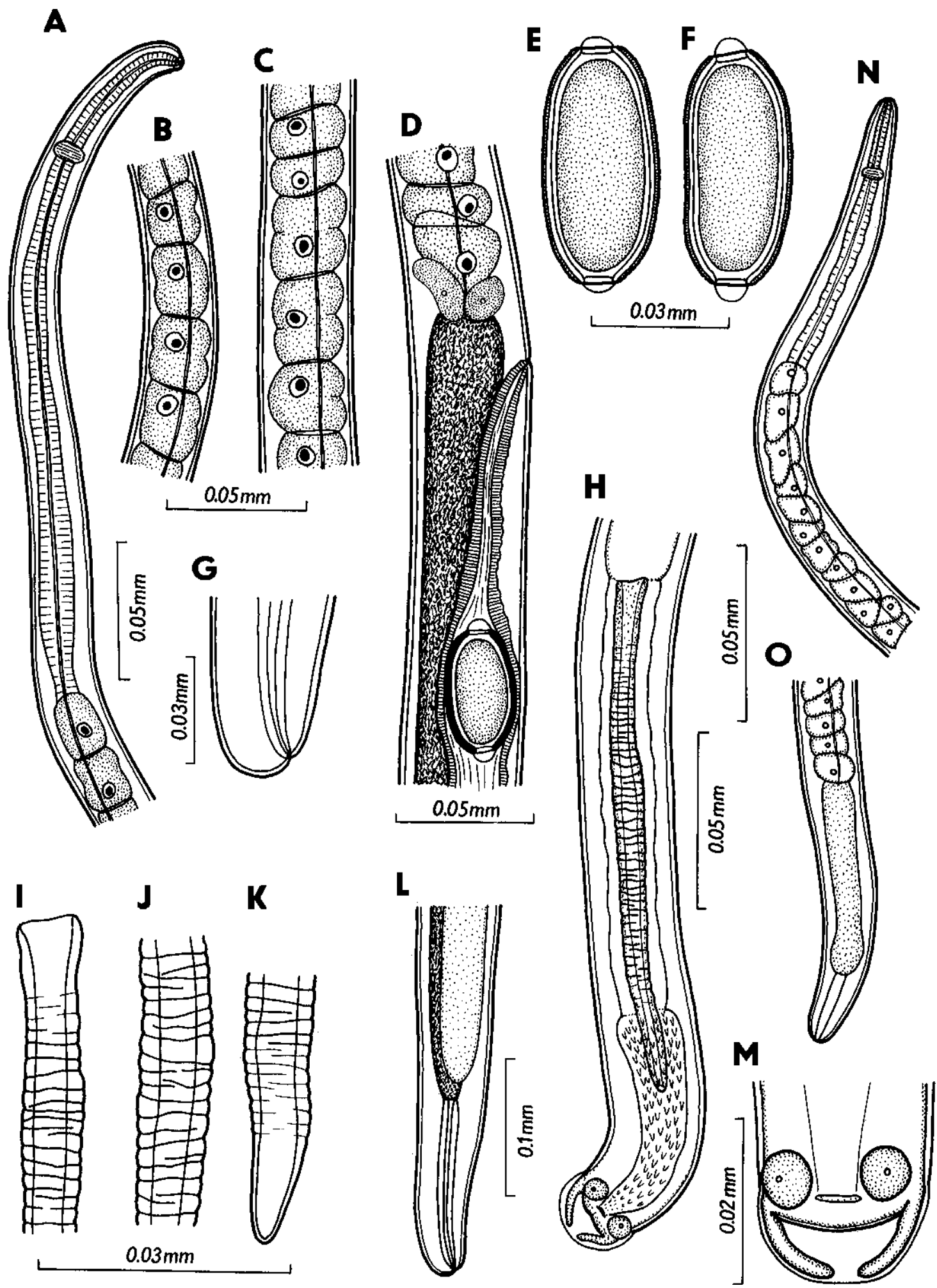

Fig. 3. Amphibiocapillaria texensis sp. n. A - anterior end; $\mathbf{B}$ - stichosome region in anterior part of stichosome; $\mathbf{C}-$ same of middle region in middle part of stichosome; $\mathbf{D}$ - region of vulva; $\mathbf{E}, \mathbf{F}$ - mature eggs; $\mathbf{G}$ - caudal end of female, lateral view; $\mathbf{H}$ posterior end of male, ventral view; I-K - proximal, middle and distal parts of spicule; $\mathbf{L}$ - posterior end of body of young female; $\mathbf{M}$ - caudal end of male, ventral view; $\mathbf{N}$ - anterior end of smallest larva; $\mathbf{O}$ - posterior end of smallest larva. 
layered, inner layer thin, hyaline, outer layer poorly developed, very thin, with fine sculpture on surface. Content of mature eggs from uterus uncleaved. Length of mature eggs including polar plugs 0.057-0.066, maximum width 0.027-0.033 $(0.063-0.066 \times 0.027-$ $0.030)$; thickness of egg wall 0.001-0.002 (0.002). Polar plugs $0.004-0.007$ (0.006-0.007) long and 0.007-0.009 (0.009) wide, height of their protruding part 0.002-0.004 (0.004). Ovary reaching posteriorly nearly to level of anterior end of rectum. Posterior end of body rounded, usually slightly ventrally curved, anal opening almost terminal. Length of rectum 0.045-0.135 (-).

Larvae (8 specimens): Smallest larvae 0.612-0.801 long and 0.020-0.021 wide. Entire oesophagus 0.4950.690 long, forming $80-86 \%$ of body length. Muscular oesophagus and stichosome $0.105-0.144$ and 0.396 0.546 , long, respectively; stichocytes $52-71$ in number. Rectum 0.030 long. More advanced juveniles 1.4011.437 long and 0.027 wide. Entire oesophagus 1.0611.067 long, forming $74-76 \%$ of body length.

$\mathrm{T}$ y $\mathrm{p}$ e $\mathrm{h}$ o s $\mathrm{t}$ : Texas blind salamander, Typhlomolge rathbuni Stejneger (Plethodontidae, Amphibia).

$\mathrm{S}$ i t e of in fection: Intestine.

$\mathrm{T}$ y p e 1 o c a 1 i t y : Artesian well at Freeman Aquatic Station, San Marcos, Hays County, central Texas, USA (holotype and allotype collected 3 September 1999).

O t h e r 1 o c a 1 i t y: Pipe Spring (San Marcos Springs), San Marcos, Hays County, central Texas, USA.

Prevale n ce and inten sit y: Artesian well: $33 \%$ (7 salamanders infected / 21 examined), 1-8 (mean 3) nematodes per salamander. Spring Pipe: 13\% (1/8), 2.

D e p o s i t i o n of ty p e s: Holotype and allotype in US National Parasite Collection, Beltsville, Maryland (Cat. Nos. 089429.00 and 089430.00), paratypes in Institute of Parasitology, ASCR, in České Budějovice (Cat. No. N752).

E t y m o 1 o g y: The specific name relates to the state of its origin, i. e. Texas (USA).

Remark: Mainly salamanders with body longer than $5 \mathrm{~cm}$ were infected; the smallest salamander (length 3.5 $\mathrm{cm})$ harboured only $A$. texensis larvae. Infected salamanders were collected in May, June and September-November.

Comments: This species has a well developed caudal bursa supported by lateral rays, strongly sclerotised spicule with transverse grooves, spinose spicular sheath and a characteristic structure of the stichosome, and evidently belongs to the genus Amphibiocapillaria Moravec, 1982, which includes intestinal and liver parasites of amphibians and reptiles (Moravec 1982, 1986). At present the genus comprises 7 species: A. bufonis (Morishita, 1926), A. combesi (Chabaud et Knoepfler, 1985), A. costacruzi (Travassos, 1932), A. tritoniscristati (Diesing, 1861) and A. tritonispunctati (Diesing, 1851) from amphibians and $A$. freitaslenti (Araujo et Gandra, 1941) and A. serpentina (Harwood, 1932) from reptiles.
Amphibiocapillaria texensis is most similar to $A$. tritonispunctati, a widely distributed intestinal parasite of holarctic caudate amphibians, differing from it mainly in the structure of the mature eggs and by a markedly shorter spicule. While the mature eggs of $A$. tritonispunctati have a conspicuously thick outer layer of the egg shell, with a characteristic structure, and with polar plugs not protruding, the eggs of $A$. texensis have the outer layer of the egg wall poorly developed, very thin and difficult to observe, and the polar plugs are distinctly protruding. The spicule of the new species is only $0.162 \mathrm{~mm}$ long by which it differs from all congeners except for the inadequately described $A$. freitaslenti, in which the spicule was not observed (this species can be distinguished by its host type [iguanid lizard] and geographical distribution [Brazil]). The usual length of the spicule in A. tritonispunctati is about $0.3 \mathrm{~mm}$, but exceptionally, it may be much smaller (about $0.2 \mathrm{~mm}$ ) in small specimens (Lomakin 1982, Moravec and Lomakin 1982, Moravec 1986).

\section{Amphibiocapillaria sp. larvae (cf. A. texensis)}

One very small larva evidently belonging to Amphibiocapillaria and probably conspecific with the new species $A$. texensis was found in the intestine of one $E$. nana (body length $4 \mathrm{~cm}$ ) collected from Pipe Spring (San Marcos Springs) on 4 April 1980.

\section{DISCUSSION}

Although no data have so far been available on the helminth parasites of the San Marcos dwarf salamander, Eurycea nana, Longley (1978), in his unpublished technical report, mentions the presence of a capillariid nematode, Capillaria sp. (detected by eggs in faeces), an unidentified trematode, and an acanthocephalan, Neoechinorhynchus sp., from the Texas blind salamander, Typhlomolge rathbuni, collected in the San Marcos area. Since our material originates from the same localities, it is highly probable that the reported Capillaria sp. was, in fact, conspecific with Amphibiocapillaria texensis, the unidentified trematode with Brachycoelium longleyi, and the Neoechinorhynchus sp. with Dendronucleata americana, the three species newly described in this paper.

The helminth fauna of both these endemic species of plethodontid salamanders, as recorded during this study, is very interesting, being composed of apparently endemic species of parasites. While the helminth fauna of $T$. rathbuni includes three species: one trematode, one nematode and one acanthocephalan, that of E. nana is formed only by one trematode and one nematode, which may be due to the small number of examined specimens. It seems that both these species of salamanders have identical species of helminths (the capillariid larva from E. nana is probably conspecific with $A$. texensis), this being probably due to the fact that 
both salamanders may come into contact in some shared environments (e.g. in San Marcos Springs). Since the spring water flows swiftly from the ground in San Marcos Springs, and since the helminths in the $T$. rathbuni captured in the outflow were mature, it is probable that the intermediate hosts of the worms are resident in the aquifer itself, and that $E$. nana acquires its infections from intermediate hosts that emerge in the outflowing water.

Although Brachycoelium longleyi and Amphibiocapillaria texensis have congeneric species parasitising North American amphibians, the record of Dendronucleata americana is quite unique, because members of the family Dendronucleatidae (2 species) were known only from fishes of the Far East. Otherwise, the occurrence of the above mentioned endemic helminth parasites in endemic salamanders of the San Marcos area is not surprising, because this area is known by many endemic species of aquatic invertebrates (some with the only known congeners on other continents) as well as a few endemic vertebrates.

The recorded parasites of the Texas blind salamander are of special interest, because this host is highly adapted to its life in the subterranean waters and, therefore, also the life cycles of these helminths must be completed in the same environment. Probably all of these parasites are biohelminths, requiring obligate intermediate hosts (aquatic snails in Brachycoelium and probably oligochaetes and ostracods in Amphibiocapillaria and Dendronucleata, respectively), which should be available in the subterranean waters. It has been shown by Longley $(1981,1986)$ that the Edwards Aquifer has a wide variety of aquatic invertebrates.

The possibility that some biohelminths complete their life cycles in the environment of subterranean waters is supported by the findings of the endemic parasitic nematode Rhabdochona longleyi Moravec et Huffman, 1988 from blind catfishes, Trogloglanis pattersoni Eigenmann and Satan eurystomus Hubbs et Bailey from the San Antonio Pool of Edwards Aquifer in Texas, USA and Rhabdochona kidderi Pearse, 1936 from the blind fish Ogilbia pearsei (Hubbs) from the Nohoch cave system in the Yucatan Peninsula (State of Quintana Roo), south-eastern Mexico (Moravec and Huffman 1988, Moravec et al. 1999).

Acknowledgements. We are grateful to Dr. Glenn Longley, the director of Edwards Aquifer Research and Data Center, Southwest Texas State University, San Marcos, who kindly provided unique host salamanders for helminthological examination. Our thanks are also due to Mrs. Irena Husáková of the Institute of Parasitology, ASCR, České Budějovice, for her technical assistance. This study was supported by grant no. 524/97/0009 from the Grant Agency of the Czech Republic.

\section{REFERENCES}

AMIN O.M. 1987: Key to the families and subfamilies of Acanthocephala, with the erection of a new class (Polyacanthocephala) and a new order (Polyacanthorhynchida). J. Parasitol. 73: 1216-1219.

BYRD E.E. 1937: Observations on the trematode genus Brachycoelium Dujardin. Proc. U.S. Nat. Mus. 84: 138199.

CHENG T.C. 1958: Studies on the trematode family Dicrocoeliidae. I. The genera Brachycoelium (Dujardin, 1845) and Leptophallus Lühe, 1909, (Brachycoeliinae). Am. Midl. Nat. 59: 67-81.

CHENG T.C., CHASE R.S. 1961: Brachycoelium stablefordi, a new parasite of salamanders, and a case of abnormal polylobation of the testes of Brachycoelium storeriae Harwood, 1932 (Trematoda: Brachycoeliidae). Trans. Am. Microsc. Soc. 80: 33-38.

COUCH J.A. 1966: Brachycoelium amblystomae sp. n. (Trematoda: Brachycoeliidae) from Amblystoma opacum. J. Parasitol. 52: 46-49.

LOMAKIN V.V. 1982: New data on the morphology of Thominx tritonispunctati $\mathrm{n}$. comb. (Nematoda, Capillariidae, a parasite of caudate amphibians. Vestn. Zool., Kiev, No. 2, pp. 44-48. (In Russian.)

LONGLEY G. 1978: Status of Typhlomolge (=Eurycea) rathbuni, the Texas blind salamander. End. Species Rep. 2, U.S. Fish and Wildlife Service, Albuquerque, New Mexico, 45 pp.
LONGLEY G. 1981: The Edwards Aquifer: earth's most diverse groundwater ecosystem? Int. J. Speleol. 11: 123128.

LONGLEY G. 1986: The biota of the Edwards Aquifer and the implications for paleozoogeography. In: P.L. Abbot and C.M. Woodruff (Eds.), The Balcones Escarpment, Central Texas. Geological Society of America, pp. 51-54.

MICHEL G.D. 1984: The biology of Capillaria sp. (Nematoda: Capillariidae) from gas bladder of sunfishes of the upper San Marcos River. M.Sc. thesis, Southwest Texas State University, San Marcos.

MORAVEC F. 1982: Proposal of a new systematic arrangement of nematodes of the family Capillariidae. Folia Parasitol. 29: 119-132.

MORAVEC F. 1984: Some helminth parasites from amphibians of Vancouver Island, B.C., western Canada. Acta Soc. Zool. Bohemoslov. 48: 107-114.

MORAVEC F. 1986: Review of capillariid nematodes (Capillariinae) parasitic in amphibians and reptiles. Part 2. Genus Amphibiocapillaria. Acta Soc. Zool. Bohemoslov. 50: $217-230+6$ Plts.

MORAVEC F., HUFFMAN D.G. 1988: Rhabdochona longleyi sp. n. (Nematoda: Rhabdochonidae) from blind catfishes, Trogloglanis pattersoni and Satan eurystomus (Ictaluridae) from the subterranean waters of Texas. Folia Parasitol. 35: 235-243. 
MORAVEC F., LOMAKIN V.V. 1982: Revision of nematodes of the genus Capillaria Zeder, 1800 from European caudate amphibians. Folia Parasitol. 29: 13-23.

MORAVEC F., SEY O. 1989: Acanthocephalans of freshwater fishes from North Vietnam. Acta Soc. Zool. Bohemoslov. 53: 89-106.

MORAVEC F., VARGAS-VÁZQUEZ J., GONZÁLEZSOLÍS D. 1999: Nematode parasites from the blind fish Ogilbia pearsei from the Nohoch cave system with remarks on Rhabdochona kidderi (Nematoda) from fishes of Yucatan, Mexico. Acta Soc. Zool. Bohem. 63: 295-300.

PARKER M.V. 1941: The trematode parasites from a collection of amphibians and reptiles. J. Tenn. Acad. Sci. 16: 27-44.

RANKIN J.S. 1938: Studies on the trematode genus Brachycoelium Duj. I. Variations in specific characters with reference to the validity of the described species. Trans. Am. Microsc. Soc. 63: 30-49.
SOKOLOVSKAYA I.L. 1962: Class Acanthocephala (Rud., 1808). In: I.E. Bykhovskaya-Pavlovskaya et al.: Key to Parasites of Freshwater Fishes of the USSR. Publ. House of the USSR Acad. Sci., Moscow - Leningrad, pp. 579616. (In Russian.)

SOKOLOVSKAYA I. L. 1971: Acanthocephalans of fishes of the Amur basin. Parazitol. Sb. 25, Publ. House Nauka, Leningrad, pp. 165-176. (In Russian.)

STUNKARD H.W. 1970: Trematode parasites of insular and relict vertebrates. J. Parasitol. 56: 1041-1054.

YAMAGUTI S. 1971: Synopsis of Digenetic Trematodes of Vertebrates. Part I, II. Keigaku Publishing Co., Tokyo, 1074 pp. + 349 Plts.

YOUNG W.C., WHITESIDE B.G., LONGLEY G., CARTER N.E. 1973: The Guadeloupe-San Antonio-Nueces River basin project. Phase I. Review of existing biological data. Final Report to Texas Water Development Board, Aquatic Station, Southwest Texas State University, Jan. 31, 1973.

Accepted 2 February 2000 